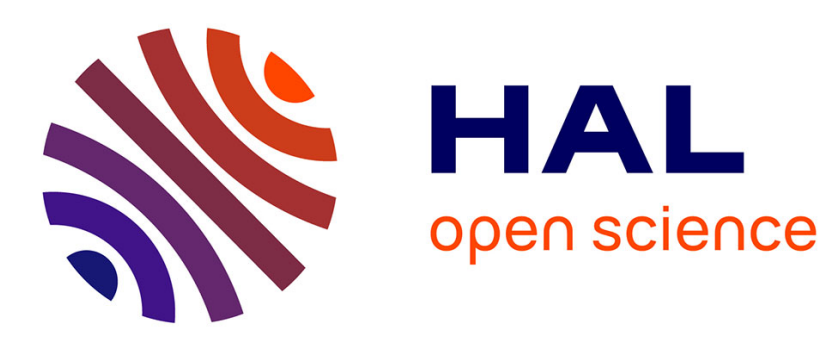

\title{
Evaluation of ATP photometer for toxicity testing using Microtox luminescent bacterial reagent
} Judy Awong, Gabriel Bitton, Ben Koopman, Jean-Louis J.-L. Morel

\section{To cite this version:}

Judy Awong, Gabriel Bitton, Ben Koopman, Jean-Louis J.-L. Morel. Evaluation of ATP photometer for toxicity testing using Microtox luminescent bacterial reagent. Bulletin of Environmental Contamination and Toxicology, 1989, 43 (1), pp.118-122. hal-02726351

\section{HAL Id: hal-02726351 \\ https://hal.inrae.fr/hal-02726351}

Submitted on 2 Jun 2020

HAL is a multi-disciplinary open access archive for the deposit and dissemination of scientific research documents, whether they are published or not. The documents may come from teaching and research institutions in France or abroad, or from public or private research centers.
L'archive ouverte pluridisciplinaire HAL, est destinée au dépôt et à la diffusion de documents scientifiques de niveau recherche, publiés ou non, émanant des établissements d'enseignement et de recherche français ou étrangers, des laboratoires publics ou privés. 


\title{
Evaluation of ATP Photometer for Toxicity Testing Using Microtox Luminescent Bacterial Reagent
}

\author{
Judy Awong, ${ }^{1}$ Gabriel Bitton, ${ }^{1}$ Ben Koopman, ${ }^{1}$ and Jean Louis Morel ${ }^{2}$
}

1Department of Environmental Engineering Sciences, University of Florida, Gainesville, Florida, 32611 USA and 'Ėcole Nationale Superieure d'Agronomie et des Industries Alimentaries, Vandoeuvre, France

The Microtox assay, based on the inhibition of luminescence of Photobacterium phosphoreum in the presence of toxic chemicals, is widely used to assess toxicity of surface waters, complex industrial effluents, air pollutants, radiation and mycotoxins, and has some promising medical applications (Bulich 1986; Ribo and Kaiser 1987). Microtox and other shortterm microbial assays may also prove useful in predicting the toxicity of new chemicals through quantitative structure-activity relationships (QSAR) (Ribo and Kaiser 1984).

The measurement of light output from bioluminescent microorganisms or luciferase-driven reactions necessitates the use of instrumentation capable of measuring extremely low quantities of light (Kricka et al. 1984; Scholmerich et al. 1987). Light emission is measured with liquid scintillation counters (ulitzur and Weiser 1981; Ulitzur et al. 1981) or photometers/luminometers consisting of a photomultiplier tube (PMT) enclosed in a light-tight chamber. The photometers are generally equipped with a rotary shutter that protects the PMT from ambient light (Bulich 1986). This basic configuration is common to both the Microtox photometer and photometers used for ATP measurement. The Microtox photometer, in addition, is equipped with incubator wells that provide temperature control for the bacterial reagent, blanks and samples, whereas ATP photometers do not allow for such control.

Surowitz et al. (1987) have used a portable luminescence photometer to measure the light output from both cell-free and whole cells of $\underline{P}$. phosphoreum. The light output from whole cells was determined by direct reading whereas the light emmitted by the cell 
free system was integrated over a 10 -second period. A systematic study on the use of a conventional ATP photometer in the Microtox assay has not been reported, however. The present research was therefore undertaken to assess the performance of a conventional ATP photometer in comparison to the Microtox photometer for measuring inhibition of the bioluminescence of $\mathrm{P}$. phosphoreum in the presence of toxic pure chemicals and toxic wastewater.

\section{MATERIALS AND METHODS}

All chemicals were ACS grade or better and were prepared in aqueous solufions using distilled water. Those tested included $\mathrm{Cd}^{2+}\left(\mathrm{CdCl}_{2} 2 \mathrm{H}_{2} \mathrm{O}\right), \mathrm{Cu}^{2+}\left(\mathrm{CuSO}_{4}\right.$ $\left.5 \mathrm{H}_{2} \mathrm{O}\right)$, formaldehyde, and sodium dodecyl sulfate (SDS). The $\mathrm{pH}$ of the chemical solutions was not adjusted.

The Buckman collection and activated sludge treatment system in Jacksonville, FL was used as a model wastewater system. Samples were obtained from the collection system, plant influent and secondary effluent before chlorination. Each collection system and plant influent sample was settled for one hour, then two-thirds $(2000 \mathrm{~mL})$ of the liquid volume was decanted. A $1400 \mathrm{~mL}$ aliquot of settled wastewater was mixed with $600 \mathrm{~mL}$ return activated sludge from the Buckman plant and aerated vigorously for 4.0 hours. The aeration period was followed by one hour of settling. Approximately $600 \mathrm{~mL}$ of treated effluent was decanted from the batch reactor. Samples were stored at $4^{\circ} \mathrm{C}$ for 24 hours before analysis.

Assays with an ATP photometer were carried out in parallel with the Microtox assays using aliquots of the bacterial reagent/diluent and toxicant that were prepared for Microtox. The volumes of bacterial reagent/diluent and toxicant were each $100 \mathrm{uL}$. Initial light output of the bacterial reagent was measured, followed immediately by addition of toxicant. Additional measurements of light output were taken at 5 minutes and 15 minutes. The ATP photometer was Model J4-7441 (American Instrument Company, Silver Springs, MD) used in conjunction with an integrator-timer (J4$7462 \mathrm{~A}$, American Instrument Company). Light output was detected by the photometer (0.3 sensitivity) and integrated over a 3 second interval by the integratortimer. The quantity of light emitted was monitored from the digital readout. All bioassays were carried out in a constant temperature room at $15^{\circ} \mathrm{C} . \quad \mathrm{EC}_{50}$ and percent inhibition values were calculated using the same procedures employed for Microtox assay (Beckman Instruments, 1982). 
The microtox assays were performed in duplicate using the Microtox Toxicity Analyzer Model 2055 (Microbics, Carlsbad, CA) and reagents (including freeze-dried P. phosphoreum) supplied by Microbics. Light emission by reconstituted bacterial reagent was measured immediately before addition of toxicant and again after 5 minute and 15 minute periods of contact. The respective volumes of bacterial reagent/diluent and toxicant after subsampling for the assays with ATP photometer were both $400 \mathrm{uL}$. A chart recorder was used to record the light emission measurements. Assay temperature was $15^{\circ} \mathrm{C}$. Percent inhibition and $\mathrm{EC}_{50}$ values were calculated according to procedures described by Beckman Instruments (1982).

RESULTS AND DISCUSSION

The $\mathrm{EC}_{50} \mathrm{~s}$ of the five chemicals tested are shown in Table 1. The $\mathrm{EC}_{50}$ s obtained with the ATP photometer were generally lower than the $\mathrm{EC}_{50} \mathrm{~s}$ obtained with the Microtox photometer. However, the mean difference between the two methods after 5 minute contact time was not significant $(\mathrm{P}<0.05)$.

Table 1. $\mathrm{EC}_{50}$ values $(\mathrm{mg} / \mathrm{L})$ for selected chemicals as determined by the Microtox and ATP photometers.

\begin{tabular}{|c|c|c|c|c|}
\hline Chemical & $\begin{array}{l}\text { ATP } \\
\mathrm{ATP}\end{array}$ & $\begin{array}{l}\text { Contact } \\
\text { Microtox }\end{array}$ & $\begin{array}{l}\text { 15-min } \\
\text { ATP }\end{array}$ & $\begin{array}{l}\text { Contact } \\
\text { Microtox }\end{array}$ \\
\hline $\begin{array}{l}\mathrm{Cd}^{2+} \\
\mathrm{Cu}^{2+} \\
\text { Formal dehyde } \\
\text { SDS }\end{array}$ & $\begin{array}{l}20.5 \\
0.50 \\
9.54 \\
6.22\end{array}$ & $\begin{array}{l}29.5 \\
1.33 \\
10.1 \\
3.02\end{array}$ & $\begin{array}{c}8.76 \\
- \\
- \\
4.04\end{array}$ & $\begin{array}{c}23.9 \\
- \\
- \\
1.80\end{array}$ \\
\hline
\end{tabular}

* Mean difference was not significant $(P<0.05)$.

Percent inhibition values were determined for 44 wastewater samples that were collected over a 3 month period. Highly significant correlations $(P<0.01)$ were obtained between the two methods when comparing percent inhibition at 5 minutes (Fig. 1) and 15 minutes (Fig. 2). Mean differences at either contact time were not significant $\quad(\mathrm{P}<0.05)$.

$\mathrm{EC}_{50} \mathrm{~s}$ for the two methods were calculated for the 14 samples that showed percent inhibitions of greater than $20 \%$ at a wastewater concentration of $45 \%$. Highly significant correlations $(P<0.01)$ were obtained between 
the data sets obtained with either a 5-minute contact period (Fig. 3) or 15-minute contact period (Fig.4). Mean differences between neither the 5 -min $\mathrm{EC}_{50} \mathrm{~s}$ nor the 15-min $\mathrm{EC}_{50}$ s were significant $(\mathrm{P}<0.05)$.

The highly significant correlations found between the Microtox Analyzer and the ATP Photometer and absence of significant differences between percent inhibitions or $\mathrm{EC}_{50^{\mathrm{s}}}$ found via the two methods indicate that commercially available photometers could indeed be used in lieu of the Microtox Analyzer. Reagents and freezedried preparations of luminescent bacteria can be purchased from Microbics (Carlsbad, CA). The ease of performance and suitability for use with a range of toxicants is comparable to the Microtox assay.

A significant advantage of assay with the ATP photometer is the need for smaller volumes of bacterial reagent in each cuvette. However, the problem of temperature control must be addressed. A temperature of $15^{\circ} \mathrm{C}$ may cause condensation in the circuitry (Bulich, personal communication). This problem can be avoided by placing both the photometer and the sample at $15^{\circ} \mathrm{C}$, as was done in this study.

Acknowledgments. Supported by the National Science Foundation (Grant \#CES-8619073), and Florida Department of Environmental Regulation (Contract \#WM222).

\section{REFERENCES}

Beckman Instruments (1982) Microtox system operating manual. Beckman Instruments, Carlsbad, California

Bulich AA (1986) Bioluminescence assays. In: Bitton G, Dutka BJ (eds.) Toxicity Testing using Microorganisms, vol 1. CRC Press, Boca Raton, Florida, p5 7

Chang JC, Taylor PB, Leach FR (1981) Use of the microtox assay system for environmental samples. Bull Environ Contam Toxicol 26:150-156

Dutka BJ, Kwan KK (1981) Comparison of three microbial screening tests with the microtox test. Bull Environ Contam Toxicol 27:753-757

Greene GC, Miller WE, Debacon MK, Long MA, Bartels CL (1985) A comparison of three microbial assay procedures for measuring toxicity of chemical residues. Arch Environ Contam Toxicol 14:659-667

Kricka LJ, Stanley PE, Thorpe GHG, whitehead TP (1984) Analytical Applications of Bioluminescence and Chemiluminesence. Academic Press, London. 
McFeters GA, Bond PJ, Olson SB, Tchan YT (1983) A comparison of microbial bioassays for the detection of aquatic toxicants. Water Res 17:1757-1762

Nacci D, Jackim E, Walsh R (1986) Comparative evaluation of three rapid marine toxicity tests: sea urchin early embryo growth test, sea urchin sperm cell toxicity test and microtox. Environ Toxicol and Chem $5: 521-525$

Qureshi AA, Flood KW, Thompson SR, Janhurst SM, Innis CS, Rokosh DA (1982) Comparison of a luminescent bacterial test with other bioassays for determining toxicity of pure compounds and complex effluents. In: Pearson JG, Foster RB, Bishop WE (eds.) Aquatic toxicology and harzard assessment: Fifth Conference. ASTM STP 766, American Society for Testing and Materials, p 197

Ribo JM, Kaiser KLE (1984) Toxicity of aniline derivatives to Photobacterium phosphoreum and their correlations with effects on other organisms and stuctural parameters. In: Kaiser KLE (ed) QSAR in Environmental Toxicology. D. Reidel Pub. Co., Dordrecht, Holland, p 319

Ribo JM, Kaiser KLE (1987) Photobacterium phosphoreum toxicity bioassay. 1. Test procedures and applications. Toxicity Assess 2:305-323

Schomerich J, Andreesen R, Knapp A, Ernst M, Woods WG (1987) Bioluminescence and Chemiluminescence: New Perspectives. Wiley, New York, p 600 .

Surowitz KG, Burke BE, Pfister RM (1987) Comparison of cell-free and whole cell luminescence assays in toxicity testing. Toxicity Assess 2: 17-27

Ulitzur S, Weiser I (1981) Acridine dyes and other DNA-intercalating agents induce the luminescence system of luminous bacteria and their dark variants. Proc Nat Acad Sci USA 78: 3338-3342

Ulitzur S, Weiser I, Yannai S (1981) Bioluminescence test of mutagenic agents. In: DeLuca MA, McElroy WD (eds.) Bioluminescence and Chemiluminescence. Acad Press, New York.

Received August 5, 1988; accepted February 2,1989. 